Ekspansi: Jurnal Ekonomi, Keuangan, Perbankan dan Akuntansi

ISSN (Online): 2580-7668 ISSN (Print): 2085-5230

Vol. 12, No. 2 (November 2020), Hal. 195 - 208

\title{
MODEL PENGEMBANGAN ISLAMIC MICROFINANCE BERBASIS KOPERASI SYARIAH (Studi Pada Pengrajin Mebeul Di Cipacing Kabupaten Sumedang)
}

\author{
Ropi Marlina ${ }^{1}$, Ade Nurhayati ${ }^{2}$ \\ ${ }^{1,2}$ STIE DR. Khez. Muttaqien, Purwakarta, Indonesia \\ Email Korespondensi: ropi.marlina@stiemuttaqien.ac.id
}

\begin{abstract}
This research is based on the phenomenon of problems that exist in SMEs, especially the furniture industry. The problems in question include, products, human resources and capital. The purpose of this research is to obtain a microfinance development model that can contribute to MSMEs. The results showed that the Islamic cooperative is one of the microfinance institutions that can be expected to be a solution in overcoming problems, especially capitalization in SMEs in Cipacing. With the mudharabah and musyarakah contract models, sharia cooperatives can be used as a form of financing for MSME players. In addition, Islamic cooperatives as a forum can also be used as partners for the development of furniture MSMEs in the Cipacing area of West Java. This research implies that the existence of sharia cooperatives can be used as an alternative solution for furniture SMEs actors in the Cipacing area, especially in terms of capital and marketing. The research method used is a qualitative descriptive method and the sampling technique used was Convenienc. The data source is the craftsmen at the furniture industry center in Cipacing, Sumedang Regency. The analysis tool will be used using Microsoft Excel to process the data obtained in the field.
\end{abstract}

Keywords: MSMEs, Microfinance, Sharia Cooperatives

Abstrak: Penelitian ini dasarkan pada fenomena masalah yang ada dalam UMKM khususnya industri mebeul. Permasalahan yang dimaksud meliputi, produk, SDM dan permodalan. Tujuan penelitian ini untuk memperolah sebuah model pengembangan mikrofinance yang bisa berkontribusi pada UMKM. Hasil penelitian menunjukkan bahwa koperasi syariah merupakan salah satu lembaga mikrofinance yang bisa diharapkan mampu menjadi solusi dalam mengatasi permasalahan khususnya permodalan dalam UMKM mebeul di Cipacing. Dengan model akad mudharabah dan musyarakah koperasi syariah bisa dijadikan salah satu bentuk pembiaayan terhadap pelaku UMKM. Selain itu koperasi syariah sebagai wadah juga bisa dijadikan mitra untuk pengembangan UMKM mebel yang ada di daerah Cipacing Jawa Barat. Penelitian ini berimplikasi bahwa keberadaan Koperasi Syariah bisa dijadikan alternanif solusi oleh para pelaku UMKM mebel di daerah cipacing terutama dalam hal permodalan dan pemasaran. Metode penelitian ini menggunakan metode deskriptif kualitatif dan teknik sampling yang digunakan adalah Convenienc. Sumber data adalah para pengrajin di sentra industri mebeul di Cipacing Kabupaten Sumedang. Alat analisis yang akan digunakan menggunakan microsoft excel untuk mengolah data yang didapatkan di lapangan.

Kata Kunci: UMKM, Microfinance, Koperasi Syariah,

DOI: $10.35313 /$ ekspansi.v12i2.2219 


\section{PENDAHULUAN}

Keberadaan UMKM di Indonesia sangatlah penting. Saat ini jumlah UMKM di Indonesia sebanyak 56,6 juta unit atau 99,99\% dari total pelaku usaha. Data tersebut dengan rincian yaitu Usaha Kecil sebanyak 2,017 juta unit (4,05\%), Usaha Menengah 120.253 unit (0,24\%) dan Usaha Mikro 47,702 juta unit (95,70\%). Selain itu sektor UMKM mampu menyumbang pada PDB Indonesia sebanyak Rp. 2.121,3T (53,6\%) dan perputaran investasi sebesar Rp 462,01T (46,9\%) serta mampu menyerap tenaga kerja sebanyak 91,8 juta orang (97,33\%). (Juliana, dkk; 2019)

Namun demikian pelaku usaha mikro sebagai penggerak ekonomi rakyat dan penyelamat ekonomi bangsa dengan jumlah 99,9\% (sangat dominan) tersebut, kondisinya masih termarginalkan. Hal itu ditambah dengan perhatian berbagai pihak sangat minim dan akses terhadap lembaga keuangan sangat rendah (tidak bankable). (Juliana, dkk; 2019) Selain masalah diatas, masalah yang seringkali muncul pada UMKM yaitu; sumber permodalan masih minim, terjerat rentenir, daya saing produk, sumber daya manusia yang rendah, dan minimnya penguasaan ilmu pengetahuan serta teknologi. (Juliana, dkk; 2018, Sudaryanto; 2013). Namun demikian, potensi untuk mengembangkan sektor UMKM perlu untuk terus ditingkatkan. Salah satu peluang untuk meningkatkan jumlah pelaku UMKM adalah mulai digarapnya produk mebeul di Cipacing Kabupaten Sumedang. Dari data Badan Pusat Statistik (BPS), Potensi Desa (PODES) tahun 2014 terdapat 700 Industri Kecil dan Mikro di Kabupaten Sumedang. Dan mengalami peningkatan pada tahun 2018 sebanyak 60 industri. Hal ini menggambarkan bahwa ada peningkatan sebesar 8,6 persen mengenai jumlah Industri Kecil dan Mikro di Kabupaten Sumedang.

Namun pada kenyataannya industri mebeul ini memiliki kelemahan-kelemahan yang sifatnya potensial. Berdasarkan pra penelitian dan wawancara yang dilakukan penulis terhadap para pengrajin mebeul di Cipacing, menurut salah saorang perajin salah satu permasalahan yang dihadapi adalah kesulitan para pengrajin dalam akses permodalan dan kesulitan memasarkan produknya.

Melihat potensi dan tantangan yang harus dihadapi para perajin mebeul tersebut, maka konsep pengembangan islamic microfinance berbasis Koperasi Syariah ini diharapkan bisa menjadi jawaban atas permasalahan tersebut. Karena lembaga keuangan mikro Islam sudah menunjukkan perkembangan yang menjanjikan. Dimana dalam konsep berbasis Koperasi Syariah ini, pelaku usaha bisa terhindar dari aktifitas yang diharamkan dan hal-hal yang sekiranya bertentangan dengan agama serta pada akhirnya bisa memberikan dampak kemaslahatan bagi masyarakat. Sebagaimana yang diungkapkan oleh Juliana, (2017) bahwa Pola koperasi konvensional seperti; integritas SDM yang masih kurang dan belum sesuai dengan nilai-nilai Islam, hasil produksi tidak disandarkan pada aspek-aspek syariah hingga permodalan masing menggunakan riba. Padahal bagi seorang muslim, agama memiliki peran penting dalam kehidupan, sehingga segala aktifitas hendaklah berpedoman pada agama termasuk diantaranya daalam hal usaha. 


\section{TINJAUAN PUSTAKA}

\subsection{UMKM}

Menurut (M.Tohar,1999) definisi usaha kecil dari berbagai segi tersebut adalah sebagai berikut:

a. Berdasarkan Total Asset Berdasarkan total asset, pengusaha kecil adalah pengusaha yang memiliki kekayaan bersih paling banyak Rp 200.000.000,00 ( dua ratus juta rupiah) tidak termasuk tanah dan bangunan tempat membuka usaha.

b. Berdasarkan Total Penjualan Bersih Per Tahun Berdasarkan hal ini pengusaha kecil adalah pengusaha yang memiliki hasil total penjualan bersih per tahun paling banyak Rp 1.000.000.000 (satu miliar rupiah).

c. Berdasarkan Status Kepemilikan Dari segi ini, didefinisikan bahwa pengusaha kecil adalah usaha berbentuk perseorangan, bisa berbadan hukum atau tidak berbadan hukum yang didalamnya termasuk koperasi.

Berdasarkan UU No. 1 tahun 1995, usaha kecil dan menengah memiliki kriteria sebagai berikut:

1. Kekayaan bersih paling banyak $\mathrm{Rp} 200$ juta tidak termasuk tanah dan bangunan tempat usaha.

2. Memiliki hasil penjualan tahunan paling banyak $\mathrm{Rp} 1$ miliar.

3. Milik Warga Negara Indonesia (WNI)

4. Berdiri sendiri, bukan merupakan anak perusahaan atau cabang perusahaan yang dimiliki atau dikuasai usaha besar.

5. Bentuk usaha orang per orang, badan usaha berbadan hukum/tidak, termasuk koperasi.

6. Untuk sektor industri, memiliki total asset maksimal Rp 5 miliar.

7. Untuk sektor non industri, memiliki kekayaan bersih paling banyak Rp 600 juta (tidak termasuk tanah dan bangunan tempat usaha), atau memiliki hasil penjualan tahunan maksimal Rp 3 miliar pada usaha yang dibiayai. Menurut BPS pada seminar di Kementerian Negara Koperasi dan UKM Tahun 2009, landasan hokum penyusunan variabel UMKM 2006-2008 adalah UU No. 20 tahun 2008 tentang UMKM meliputi:

a. Usaha mikro: memiliki kekayaan paling banyak Rp.50.000.000,- atau hasil penjualan tahunan paling banyak $\mathrm{Rp} 300.000 .000$,-

b. Usaha kecil: memiliki kekayaan bersih > Rp. 50.000.000,- sampai dengan Rp 500.000.000,- atau hasil penjualan tahunan > Rp. 300.000.000,- sampai Rp.2.500.000.000,- 
c. Usaha menengah; memiliki kekayaan bersih > Rp.500.000.000,- sampai denga $R p$ 10.000.000,- atau hasil penjualan > Rp 2.500.000.000,- sampai dengan Rp 50.000.000.000,-.

\subsection{Sentra Industri}

Definisi Menurut Surat Keputusan Menteri Negara Koperasi dan UKM No: 32/Kep/M.KUKM/IV/2002,tanggal 17 April 2002 tentang Pedoman Penumbuhan dan Pengembangan Sentra UKM, Sentra didefinisikan sebagai pusat kegiatan di kawasan/lokasi tertentu dimana terdapat UKM yang menggunakan bahan baku/sarana yang sama, menghasilkan produk yang sama/sejenis serta memiliki prospek untuk dikembangkan menjadi klaster. Sedangkan klaster adalah pusat kegiatan UKM pada sentra yang telah berkembang, ditandai oleh munculnya pengusaha-pengusaha yang lebih maju, terjadi spesialisasi proses produksi pada masingmasing UKM dan kegiatan ekonominya saling terkait dan saling mendukung. Berdasarkan eksistensi dinamisnya, industri kecil dan rumah tangga di Indonesia dapat dibagi ke dalam tiga kelompok kategori yaitu (Suhartini, 2013):

a. Industri lokal, yaitu kelompok jenis industri yang menggantungkan kelangsungan hidupnya kepada pasar setempat yang terbatas, serta relatif tersebar dari segi lokasinya.

b. Industri sentra, yaitu kelompok jenis industri yang dari segi satuan usaha mempunyai skala kecil, tetapi membentuk suatu pengelompokan atau kawasanproduksi yang terdiri dari kumpulan unit usaha yang menghasilkan barang sejenis.

c. Industri mandiri, yaitu kelompok jenis industri yang masih mempunyai sifatsifat industri kecil, namun telah berkemampuan mengadakan teknologi produksi yang cukup canggih.

Menurut Badan Pusat Statistik (BPS) Industri Kecil adalah perusahaan industri yang tenaga kerjanya antara 5-19 orang sedangkan Industri Mikro adalah perusahaan industri yang tenaga kerjanya antara 1-4 orang. Penggolongan perusahaan industri pengolahan ini semata-mata hanya didasarkan kepada banyaknya tenaga kerja yang bekerja, tanpa memperhatikan apakah perusahaan itu menggunakan mesin tenaga atau tidak, serta tanpa memperhatikan besarnya modal perusahaan itu (BPS, 2016). Sedangkan berdasarakan Undang-undang Republik Indonesia No 20 Tahun 2008 Tentang Usaha Mikro, Kecil dan Menengah pada bab IV pasal 6 kriteria usaha mikro (UUD, 2008, hal. 6) adalah sebagai berikut:

1) Memiliki kekayaan bersih paling banyak Rp 50.000.000 (lima puluh juta rupiah) tidak termasuk tanah dan bangunan tempat usaha atau; 
2) Memiliki hasil penjualan tahunan paling banyak Rp 300.000 .0000 (tiga ratus juta rupiah).

Sedangkan usaha kecil adalah sebagai berikut:

1) Memiliki kekayaan bersih lebih dari Rp. 50.000 .000 (lima puluh juta rupiah) sampai dengan paling banyak Rp 500.000.000 (lima ratus juta rupiah) tidak termasuk tanah dan bangunan tempat usaha atau;

2) Memiliki hasil penjualan tahunan lebih dari $\mathrm{Rp} 300.000 .000$ (tiga ratus juta rupiah) sampai dengan paling banyak Rp. 2.500.000.000 (dua milyar lima ratus juta rupiah).

\subsection{Koperasi Syariah}

Secara bahasa, kata koperasi berasal dari kata bahasa inggris cooperation yang berarti usaha bersama.(Revrisond Baswir, 2000) Sedangkan dalam bahasa Arab, Koperasi disebut syirkah yang berarti al- Ikhtilath, yaitu suatu perserikatan/perkongsian.(M. Zaidi A, 2003) Menurut Undang-Undang Nomor 25 Tahun 1992 Pasal 1 Ayat 1 tentang perkoperasian menyatakan bahwa koperasi adalah "badan usaha yang beranggotakan orang seorang atau badan hukum koperasi dengan melandaskan kegiatannya berdasarkan prinsip koperasi dan sekaligus sebagai gerakan ekonomi rakyat yang berdasar atas asas kekeluargaan”.(acehmillano.wordpress.com)

Pengertian ini hampir sama dengan koperasi syariah, yaitu badan usaha koperasi yang kegiatannya bergerak di bidang pembiayaan, investasi, dan simpanan dengan menggunakan prinsip syariah yaitu pola bagi hasil atau sering disebut dengan koperasi jasa keuangan Syariah Koperasi Syariah adalah jenis usaha bersama yang beranggotakan orang seorang atau badan hukum, dengan sistem kekeluargaan yang dalam pelaksanaannya berlandaskan atas prinsip-prinsip syariah. Menurut Permen K.UMKM no. 35.3Per/M.KUMKM/X/2007, "Koperasi Syariah didefinisikan sebagai Koperasi Jasa Keuangan Syariah, yaitu Koperasi yang kegiatan usahanya bergerak di bidang pembiayaan, investasi, dan simpanan sesuai pola syariah.”

\section{METODE PENELITIAN}

Dalam penelitian ini menggunakan metode deskriptif kualitatif. Metode deskriptif digunakan untuk memperoleh deskripsi yang lengkap dan akurat dari suatu situasi (Kuncoro, 2011). Adapun Pendekatannya menggunakan survey explanatory artinya penelitian ini diadakan untuk memperoleh fakta-fakta, mencari keterangan-keterangan faktual serta berusaha untuk menggabarkan gejala-gejala dari praktek yang sedang berlansung. (M.Nazir, 1988)

Teknik sampling yang digunakan adalah Convenience. Convenience sampling adalah pengambilan sampel didasarkan pada ketersediaan elemen dan kemudahan untuk mendapatkannya. Sampel diambil/terpilih karena sampel tersebut ada pada tempat dan waktu yang tepat.(Sugiarto, dkk (2001). Teknik ini digunakan untuk mempermudah peneliti dalam memberikan penilaian terhadap implementasi pengelolaan UMKM dengan cara mencari konsumen yang bersedia diminta 
tanggapannya. Dalam penelitian ini sampel yang di teliti adalah 40 orang pelaku UMKM Mebeul Cipacing.

\section{HASIL DAN PEMBAHASAN}

\subsection{Sejarah Industri Mebeul Cipacing}

Cipacing adalah sebuah desa yang terletak di Kecamatan Jatinangor Kabupaten Sumedang. Posisi yang menjorok sehingga berbatasan dengan kabupaten Bandung. Selain itu letak geografis Desa Cipacing yang dilalui oleh jalan nasional membuat desa ini sangat strategis untuk jalur ekonomi masyarakat. Setidaknya di desa ini terdapat 16 jenis kerajinan yang dikembangkan seperti makanan, lukisan, patung, mebeul dan alat musik. Salah satu kerajinan yang dihasilkan dari masyarakat Desa Cipacing adalah mebeul.

Untuk produk mebeul yang dihasilkan masyarakat Desa Cipacing sejauh ini sudah dipasarkan ke tingkat nasional mulai dari pulau Kalimantan, Sumatera dan Sulawesi. Berdasarkan hasil penelusuran bisnis mebeul Cipacing ini diawali sejak tahun 1980 dengan digagas oleh para pendatang, yaitu $\mathrm{Hj}$. Eem, $\mathrm{Hj}$. Emah, $\mathrm{Hj}$. Atih, $\mathrm{H}$. Mamat , H. Jupri. Rata rata para pengrajin mebeul di Cipacing berasal dari daerah Malangbong Garut dan Cicadas Kota Bandung. Hingga saat ini bisnis mebeul di Desa Cipacing sudah banyak, bahkan ada kawasan khusus RW 06 Babakan Sukamulya, satu RW hampir semua pendudukanya menggeluti bisnis mebeul.

Tabel 1. Gambaran Umum Sampel

\begin{tabular}{|c|c|c|}
\hline No & Karakteristik & Keterangan \\
\hline 1 & Jenis Kelamin & $\begin{array}{l}\text { Laki-laki berjumlah } 30 \text { orang dan perempuan berjumlah } 10 \\
\text { orang }\end{array}$ \\
\hline 2 & Rata Rata Usia & $\begin{array}{l}30-35 \text { th }=7 \\
36-40 \text { th }=11 \\
41-45 \text { th }=8 \\
46-50 \text { th }=8 \\
>50 \text { th }=6 \\
\text { Dari segi usia dapat disimpulkan bahwa kebanyakan pelaku } \\
\text { usaha mebeul didominsd ioleh kalangan muda yakni usia 36- } \\
40 \text { tahun sebanyak } 11 \text { orang dan kalangan tertua usia }>50 \\
\text { tahun sekitar } 6 \text { orang }\end{array}$ \\
\hline 3 & Rata Rata Pendidikan & $\begin{array}{l}\mathrm{SD}=2 \\
\mathrm{SMP}=9 \\
\mathrm{SMA}=29 \\
\text { Pendidikan para pelaku UMKM yang ada di Cipacing rata- } \\
\text { rata tingkat SMA sebanyak } 29 \text { orang, sedangkaan yang } \\
\text { berpendidikan sampai tingkat SD hanya } 2 \text { orang, sisanya } 9 \\
\text { orang dari tingkat SMP }\end{array}$ \\
\hline 4 & Lama Menjalankan Usaha & Rata-rata menjalankan usaha selama 11 tahun \\
\hline 5 & Bentuk Usaha & Bentuk usaha hampir semuanya perseorangan \\
\hline 6 & Ijin Usaha & $\begin{array}{l}\text { Ijin usaha yang dimilki sebanyak } 14 \text { orang memliki SIUP } \\
\text { dan hanya } 17 \text { orang yang memiliki NPWP }\end{array}$ \\
\hline 7 & Omset per bulan & $\begin{array}{l}\text { Omset UMKM mebeul di Cipacing berkisar antara 20-150 } \\
\text { juta per bulan }\end{array}$ \\
\hline
\end{tabular}




\begin{tabular}{|l|l|l|}
\hline No & \multicolumn{1}{|c|}{ Karakteristik } & \multicolumn{1}{|c|}{ Keterangan } \\
\hline 8 & Voume Penjualan & $\begin{array}{l}\text { Volume penjualan rata-rata berkisar antara 10-70 set kursi } \\
\text { per bulannya }\end{array}$ \\
\hline 9 & Kisaran Harga & $\begin{array}{l}\text { Harga per kursi besekitar antara Rp.1.000.000,0- } \\
\text { Rp.3.000.000,00/set }\end{array}$ \\
\hline 10 & Jangkauan Pemasaran & $\begin{array}{l}\text { Jangkauan pemasaran mebeul selain pulau Jawa juga } \\
\text { sampai ke pulau Kalimantan, Sumatra dan Bali }\end{array}$ \\
\hline
\end{tabular}

Analisa Lapangan UMKM Mebeul Cipacing

Setelah menalukan survey lapangan dengan cara terjun langsung kepada para pengrajin mebeul yang berada di Cipacing maka ditemukan beberepa temuan sebagai berikut:

1. Dalam prakteknya berdasarkan hasil wawancara yang dilakukan oleh penulis, para pelaku UMKM mengalami beberapa kendala. Kendala ini yang membuat para pelaku UMKM sulit untuk mengembangkan bisnisnya lebih besar. Kendala-kendala tersebut diantaranya; masalah keuangan, persaingan pasar, bahan baku, sumber daya manusia, pemasaran dan perizinan.

2. Pada umumnya para pelaku UMKM mebeul yang berada di Cipacing memerelukan tambahan modal baik untuk operasional maupun pengembangan usaha. Selama ini mereka melakukan aktifitas bisnis dengan modal sendiri yang seadanya. ataupun melakukan pinjaman kepada Lembaga Keuangan perbankan.

3. Secara umum mereka mengajukan modal pada lembaga keuangan konvensional yang berbasis riba. untuk jumlah pinjaman cukup beragam mulai dari 10 juta samapai dengan 100 juta

4. Terdapat juga beberapa pengrajin mebeul yang melakukan pinjaman modal kepada bank keliling / rentenir.

5. Para pengrajin mengeluhkan dengan bunga yang diberikan oleh pihak pemberi pinjam, dengan jumlah bunga yang cukup besar.

6. Ketika dijelaskan opini mengenai Koperasi Syariah sebagai wadah bagi para pengrajin untuk bisa mengoptimalkan bisnis mebeulnya, kebanyakan mereka setuju adanya koperasi tersebut. Apalagi dengan prinsip-prinsip syariah yang diharapkan bagi mereka bisa membawa berkah. Sebagai catatan para pengrajin pada umumnya tahu dosa dan bahaya riba yang selama ini mereka lakukan, namun dengan alasan kebutuhan yang mendesak untuk permodalan akahirnya mereka mengambil modal kepada institusi/perorangan yang dianggap mudah dan cepat, yaitu perbankan konvensional dan rentenir.

7. Berkenaan dengan hal itu, adanya koperasi syariah sebagai salah satu institusi microfinance yang dapat memeberikan solusi permodalan tentu keberadaannya sangat diharapkan.

\subsection{Beberapa model dalam pengembangan UMKM}

Sejauh ini sudah terdapat beberapa role model dalam pengembangan microfinance yang diterapkan di berbagai negara. Beberapa model tersebut seperti; Association 
Model, Bank Guarantees Model, Community Banking Model, Cooperatives Model, Credit Unions Model, Grameen Model, Group Model, Individual Model, Intermediaries Model, NGO Model, Peer Pressure Model, ROSCA Model, Small Business Model, Villagen Banking Model, Partnerhip Model, Interest free Model. (J. Efendi, dkk; 2017)

Association Model adalah sebuah model bisnis dimana komunitas masyarakat membentuk sebuah asosiasi dilingkungannya dimana berbagai kegiatan keuangan mikro (dan lainnya) dimulai. Kegiatan semacam itu mungkin termasuk tabungan. Asosiasi ini biasanya terdiri dari pemuda atau perempuan. Bentuk asosiasi yang ada biasanya meliputi asosiasi politik, agama, budaya, bahkan struktur pendukung untuk usaha mikro dan masalah berbasis pekerjaan lainnya seperti asosiasi Usaha Mikro Kecil Menengah (UMKM/SMEs). Di beberapa negara sebuah asosiasi bisa merupakan sebuah lembaga berbadan hukum yang memiliki yang memiliki keuntungan tertentu seperti pengumpulan biaya, asuransi, keringanan pajak, dan tindakan perlindungan bagi angotanya. Perbedaan dibuat antara asosiasi, kelompok masyarakat, organisasi masyarakat, dll. Di satu sisi (yang berbasis massa, berbasis komunitas) dan LSM, dll. Yang pada dasarnya adalah organisasi eksternal. (Hari Srinivas, 2015)

Bank Guarantees Model adalah sebuah model bisnis microfinance dimana bank memberikan jaminan kepada debitur bahwa kewajiban debitur akan terpenuhi. Dengan kata lain, jika debitur gagal untuk melunasi utang, bank akan menutupinya. Jaminan ini dapat diatur secara eksternal (melalui donor / donasi, lembaga pemerintah dll) atau secara internal (menggunakan simpanan anggota). Sebuah bank garansi memungkinkan pelanggan (debitur) untuk mendapatkan barang, membeli peralatan, atau penarikan pinjaman untuk memperluas kegiatan usahanya. Pinjaman yang diperoleh dapat diberikan secara langsung kepada individu, atau kepada kelompok tertentu seperti pada kelompok UM/SMEs. (J. Efendi, dkk; 2017) Beberapa organisasi internasional dan PBB telah menciptakan dana jaminan internasional dimana bank dan LSM dapat berlangganan, meminjamkan atau memulai program kredit mikro. (Hari Srinivas, 2015)

Community Banking Model adalah sebuah model bisnis dimana masyarakat dibentuk atau diarahkan untuk mendirikan lembaga semi formal atau formal yang memiliki fungsi sebagai penyalur dana keuangan mikro. Lembaga-lembaga tersebut biasanya dibentuk oleh bantuan ekstensif dari LSM dan organisasi lainnya. Selain itu lembaga ini juga melatih anggota masyarakat dalam berbagai kegiatan keuangan dari community Banking. Lembaga-lembaga ini mungkin memiliki komponen tabungan dan juga pembiayaan lain yang menghasilkan pendapatan. Dalam banyak kasus, Community Banking juga merupakan bagian dari program pengembangan masyarakat yang menggunakan insentif keuangan sebagai bujukan agar masyarakat mamelakukan usaha. Model bisnis Community Banking ini erat kaitannya dengan model bisnis Perbankan desa. (J. Efendi, dkk; 2017)

Cooperatives Model adalah sebuah model bisnis microfinance yang lebih dikenal dengan istilah Koperasi. Koperasi adalah asosiasi otonom dari orang-orang yang bergabung secara sukarela untuk memenuhi kebutuhan dan tujuan bersama. Koperasi 
didirikan sebagai upaya memenuhi aspirasi dan kebutuhan ekonomi, sosial, dan budaya para anggota koperasi. Koperasi memiliki ciri kepemilikan bersama dan diatur secara demokratis. Beberapa koperasi memiliki fungsi simpan pinjam dan pembiayaan kepada anggotanya. (J. Efendi, dkk; 2017)

Credit Unions Model adalah sebuah model bisnis microfinance yang dikenal juga dengan istilah Koperasi Simpan Pinjam. Koperasi Simpan Pinjam adalah lembaga keuangan swadaya anggota yang didirikan oleh anggota kelompok atau organisasi tertentu yang setuju untuk menyimpan uang mereka bersama-sama dan untuk memberikan pinjaman kepada satu sama lain pada tingkat bunga yang wajar. Koperasi Simpan Pinjam ini biasanya berdiri karena ada kesamaan kultur pada sesama anggotanya, seperti contoh serikat buruh, persatuan gereja, ikatan sosial yang sama, dll. Keanggotaan Koperasi Simpan Pinjam ini bersifat terbuka untuk semua anggota terlepas dari ras, agama, warna kulit atau kepercayaan. Koperasi Simpan Pinjam bersifat demokratis tujuan utama tidak untuk mencari keuntungan. Koperasi Simpan Pinjam ini dimiliki dan diatur oleh para anggotanya, sehingga setiap anggota memiliki suara yang sama dalam pemilihan direksi dan wakil komite. (J. Efendi, dkk; 2017) Credit union dibentuk oleh sekelompok orang yang memiliki ikatan yang sama; bekerja untuk majikan yang sama; tergabung dalam gereja yang sama, serikat pekerja, persaudaraan sosial, dll .; atau tinggal / bekerja di komunitas yang sama. Keanggotaan credit union terbuka untuk semua orang yang tergabung dalam kelompok tersebut, tanpa memandang ras, agama, warna kulit atau kepercayaan. Anggota kelompok / koperasi mengontrol serikat sendiri dan menawarkan layanan mulai dari menabung mobilisasi untuk perpanjangan kredit dan pemulihannya. Namun, serikat kredit umumnya terkait dengan beberapa tubuh puncak yang mengawasi, memberi mereka pelatihan, dan memantau kinerja mereka.(http://gifr.net/gifr2013/ch_11)

Grameen Model berasal dari pedesaan Chittagong, Bangladesh melalui sebuah universitas profesor, Muhammad Yunus pada tahun 1976 sebagai percobaan. Banyak motivasi dibelakang idenya adalah perlunya kredit oleh peminjam miskin di daerah yang pada akhirnya akan membebaskan mereka dari cengkeraman para rentenir informal (karena yang termiskin dari yang miskin tidak memiliki akses ke kredit komersial) (Jain \& Mansuri 2003). Yunus memulai sebuah proyek memberikan pinjaman tanpa jaminan dari kantongnya sendiri kepada penduduk desa yang miskin untuk mendapatkan penghasilan kegiatan menghasilkan seperti menganyam bangku bambu dan membuat pot (Morduch 1999). Model tersebut dibentuk dari ide pinjaman kelompok, kelompok dibentuk secara sukarela oleh penduduk desa. Dibantu dengan tingkat pembayaran yang tinggi, proyek tersebut berkembang pesat desa dan wilayah tetangga dan saat ini memiliki 1.195 cabang, bekerja di 43.681 desa, dengan jumlah peminjam mencapai 3,12 juta yang 95 persennya adalah perempuan (Yunus 2004).

Model Grameen adalah sebuah unit bank didirikan dengan seorang Manajer Lapangan dan sejumlah pekerja bank, yang meliputi area sekitar 15 hingga 22 desa. Manajer dan pekerja memulai dengan mengunjungi desa-desa untuk membiasakan diri dengan lingkungan lokal tempat mereka akan beroperasi dan mengidentifikasi calon klien, serta menjelaskan tujuan, fungsi, dan cara kerja bank kepada penduduk 
setempat. Dibentuk kelompok yang terdiri dari lima calon peminjam; pada tahap pertama, hanya dua dari mereka yang berhak dan menerima pinjaman. Grup tersebut diobservasi selama sebulan untuk melihat apakah anggotanya mematuhi aturan bank. Hanya jika dua peminjam pertama melunasi pokok ditambah bunganya selama jangka waktu lima puluh minggu barulah anggota kelompok lainnya memenuhi syarat untuk mendapatkan pinjaman. Karena pembatasan ini, ada tekanan kelompok yang substansial untuk menjaga catatan individu tetap jelas. Dalam pengertian ini, tanggung jawab kolektif kelompok berfungsi sebagai jaminan atas pinjaman.(Hari Srinivas, 2015)

Group Model adalah sebuah model bisnis microfinance yang menekankan kepada adanya kekuatan dari sebuah grup. Filosofi dasar Group Model terletak pada fakta bahwa kekurangan dan kelemahan pada tingkat individu diatasi dengan tanggung jawab kolektif dan keamanan yang diberikan oleh pembentukan kelompok orang tersebut. Model ini ada untuk beberapa tujuan diantaranya: mendidik, membangun kepedulian, kesadaran dandaya tawar kolektif. Model bisnis ini berkaitan erat dan telah menginspirasi banyak model pinjaman lainnya diantaranya Grameen Model, Community Banking Model, Village Banking Model dan lainnya. (J. Efendi,dkk; 2017)

Salah satu contoh Model Grup adalah "Kewajiban Bersama". Ketika sebuah grup mengambil pinjaman, mereka bersama-sama bertanggung jawab untuk membayar kembali pinjaman tersebut ketika salah satu anggota grup gagal membayar. (Hari Srinivas, 2015)

Individual Model adalah model bisnis microfinance dimana kredit mikro diberikan langsung kepada peminjam. Model bisnis ini dilakukan oleh individu satu kepada individu lainya secara langsung tanpa melalui sebuah lembaga. Model individu, dalam banyak kasus, merupakan bagian dari program 'kredit plus' yang lebih besar, di mana layanan sosio-ekonomi lain seperti pengembangan keterampilan, pendidikan, dan layanan penjangkauan lainnya disediakan. (J. Efendi,dkk; 2017)

Intermediaries Model adalah sebuah model bisnis microfinance dimana terdapat organisasi 'perantara' antara pemberi pinjaman dan peminjam. Perantara memainkan peran penting dalam membangkitkan kesadaran kredit dan pendidikan di antara para peminjam termasuk, dalam beberapa kasus, memulai program tabungan. Aktivitas ini diarahkan untuk meningkatkan 'kelayakan kredit' peminjam ke tingkat yang cukup untuk membuatnya menarik pemberi pinjaman.Tautan yang dikembangkan oleh perantara dapat mencakup pendanaan, tautan program, pelatihan dan pendidikan, dan penelitian. Kegiatan semacam itu dapat berlangsung di berbagai tingkatan dari tingkat internasional dan nasional hingga regional, lokal dan individu.Perantara dapat berupa pemberi pinjaman perorangan, LSM, program usaha mikro / kredit mikro, dan bank komersial (untuk program yang dibiayai pemerintah). Pemberi pinjaman dapat berupa lembaga pemerintah, bank komersial, donor internasional, dll.(Hari Srinivas, 2015)

NGO Model atau dikenal dengan istilah Lembaga Swadaya Masyarakat (LSM) muncul sebagai pemain kunci di bidang kredit mikro. Mereka telah memainkan peran perantara dalam berbagai dimensi. LSM telah aktif dalam memulai dan berpartisipasi dalam program kredit mikro. LSM juga menciptakan kesadaran akan pentingnya kredit 
mikro dalam masyarakat. LSM telah mengembangkan sumberdaya dan alat bagi masyarakat dan organisasi kredit mikro untuk memantau kemajuan dan mengidentifikasi praktek-praktek yang baik. Mereka juga telah menciptakan kesempatan untuk belajar tentang prinsip-prinsip dan praktek kredit mikro. Termasuk didalamnya mendukung kegiatan publikasi karya ilmiah, lokakarya, seminar, dan program pelatihan. (J. Efendi, dkk; 2017)

Peer Pressure Model lebih ditekankan kepada kedekatan antara individu pemberi pinjaman kepada individu peminjam. Model ini disebut juga tekanan teman sebaya menggunakan hubungan moral dan hubungan lain antara peminjam dan peserta proyek untuk memastikan partisipasi dan pembayaran kembali dalam program kredit mikro. Teman sebaya bisa menjadi anggota lain dalam kelompok peminjam (di mana, kecuali peminjam awal dalam kelompok melunasi, anggota lainnya tidak menerima pinjaman. Oleh karena itu, tekanan diberikan pada anggota awal untuk membayar kembali); tokoh masyarakat (biasanya diidentifikasi, dibina dan dilatih oleh LSM eksternal); LSM itu sendiri dan petugas lapangannya; bank dll. Sistem ini digunakan juga oleh model bisnis Grameen Bank, dimana sebelum menyalurkan pembiayaanya, para petugas lapang melakukan pendekatan kepada masyarakat sehingga masyarakat mengenal lebih dekat pemberi pinjaman. Peer Pressure Model ini akan memberikan beban moral kepada peminjam untuk komitmen dalam melunasi pinjamannya. Model pembiayaan bisnis yang dilakukan relatif bervariasi antara suatu negara dengan negara lain. Misalnya, Grameen Bank yang populer di Bangladesh dan BancoSol di Bolivia sertaFINCA dan ROSCA di Afrika yang menerapkan pola pinjaman berkelompok dengan mekanisme jaminan kelompok (joint liability). Selain itu ada pula pola pinjaman kelompok melalui credit union dan koperasi yang menerapkan mekanisme jaminan kelompok melalui pola simpanan wajib dan simpanan sukarela. (J. Efendi, $\mathrm{dkk}$;2017)

\subsection{Koperasi Syariah dan Pengemban UMKM Mebeul Cipacing.}

Koperasi merupakan salah satu lembaga microfinace yang bisa di harapakan mampu berkontribusi dalam membatu pengembangan para pelaku UMKM di Cipacing. Dalam prakteknya koperasi bisa membantu melakukan pendanaan bagi para pelaku bisnis UMKM yang selama ini menjadi kendala utama yaitu berkenaan dengan permodalan.

Dengan adanya koperasi bisa dirapkan membantu masalah permodalan para pelaku bisnis UMKM mebeul Cipacing. Hal ini didasarkan dengan beberapa pertimbangan. Yaitu bisa menggunakan paa pelaku UMKM sebagai mitra koperasi syariah dengan menggunakan akad Mudharabah dan Musyarakah. Adapun penjelasan mengenai skema pembiayaan dengan akad mudharabah sebagai berikut :

Pertama, pola pembiayaan musyarakah. Musyarakah adalah suatu bentuk kerjasama antar dua orang atau lebih dalam sebuah usaha dan konsekuensi keuntungan ataiu kerugiannya ditanggung secara bersama. Dengan model pembiayaan musyarakah maka memposisikan para pengrajin atau pelaku UMKM sebagai mitra dari koperasi. Dengan ketentuan masing masing menyertakan modal jika untung maka 
akan dibagi oleh kedua belah pihak begitupun jika rugi, maka akan dilakukan hal yang sama. Dengan model pembiayaan seperti ini maka bisa dijadikan alternatif oleh para pengusaha mebeul yang selama ini mengalami kesulitan dalam hal permodalan. Sehingga dengan adanya koperasi sayariah maka kedepannya para pengrajin bisa bermitra dengan kperasi syariah dan meninggalkan pola pembiayaan konvensioanal. Adapun bagannya bisa dilihat ssebagai berikut:

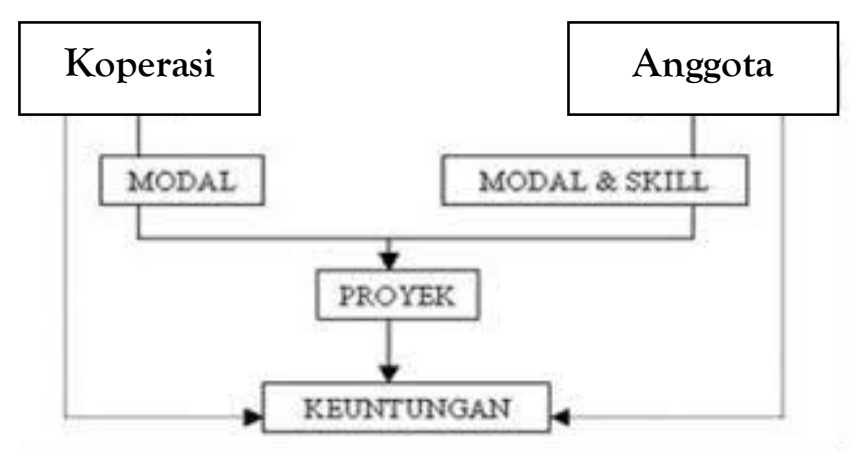

Gambar 4.1

Skema Bisnis Mebeul Cipacing dengan Akad Musyarakah

Kedua, pola pembiayaan Mudharabah. Mudharabah adalah akad kerja sama antara pemilik dana dan pengelola dana untuk melakukan kegiatan usaha. Dimana laba dibagi atas dasar nisbah' bagi hasil menurut kesepakatan. Akad Mudharabah merupakan suatu transaksi pendanaan atau investasi yang berdasarkan kepercayaan. Dalam pola ini maka memposisikan koperasi syariah sebagai shahibul maal (pemodal) dan para pengusaha UMKM mebel sebagai mudharib (penglola) kedua belah pihak bersepakat untuk melakukan akad kerja bisnis Mebel. Jika terjadi keuntungan maka dibagi sesuai dengan kesepakatan. Namun jika terjadi kerugian amak ditanggung oleh pemodal. Kecuali jika kerugian tersebut dikarenakan karena kecerobahan maka, penglola ikut bertanggung jawab dalam menggati kerugian. Berikut adalah skema bisnis mudaharabah

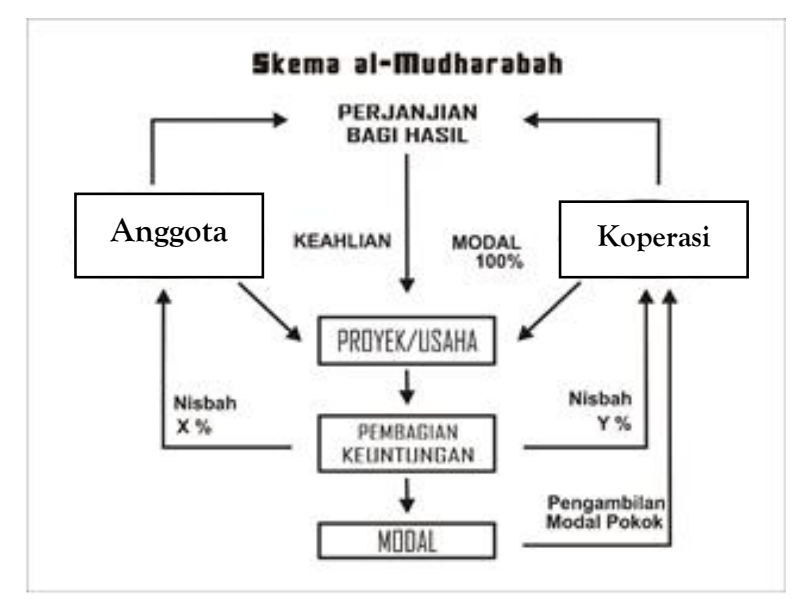

Gambar 4.2

Skema Bisnis Mebeul Cipacing dengan Akad Mudharabah 


\section{PENUTUP}

Model pengembangan microfinance dengan berbasis koperasi syariah bisa jadi solusi yang bisa dipraktekan oleh para pengusaha UMKM khususnya para pelaku industri mebeul di daerah Cipacing. Mengingat selama ini para pengrajin mebeul sangat kesulitan dalam mengatasi modal usaha. Dengan adanya koperasi syariah maka diharapkan bisa menjadi jawaban atas masalah yang dihadapi selama ini. Selain itu koperasi syariah bisa dijadikan mitra bisnis tidak hanya dalam masalah permodalan, melainkan juga dalam hal pemasaran, penyedia bahan baku dll. adapaun impliaksi dari penelitian ini semoga bisa menambah kahzanah keilmuan megenai UMKM, Koperasi syariah dan microfinance. Adanpun secara praktis maka koperasi syariah bisa menjadi sarana dan wadah bagi para pengusaha mebeul di daerah Cipacing.

\section{DAFTAR PUSTAKA}

Bryman, A (2004) Social Research Method, Oxford University Press: Unites Stated

BPS. (2016). Industri Kecil dan Mikro. [Online]. Tersedia: https://www.bps.go.id/Subjek/view/id/170\#subjekViewTab1 |accordiondaftar-subjek2. Diakses: 20 Maret 2016

Firdaus, M. (2005). Dasar dan Strategi Pemasaran Syariah. Jakarta: Renaisan.

Gupta, G.B. and Srinivasan, N.P., Entrepreneurial Development, (New Delhi: Sultan Chand \& Sons, 1992), hal. 63

Hafidhuddin, D. \& Hendri Tanjung. (2003). Manajemen Syariah dalam Praktek. Jakarta: Gema Press cet. 1.

Hari Srinivas. Microfinance-Credit Le nding Models. Continuing Research Series E059. June 2015.

Hill, C. Wee, C. Udayasankar, K. (2013). Bisnis Internasional Perspektif Asia. Jakarta: Salemba Empat.

http://gifr.net/gifr2013/ch_11.hal 127

Jain, S. \& Mansuri, G. (2003): A little at a time: The use of regularly scheduled repayments in microfinance programs, in: Journal of Development Economics, Vol. 72, No. 1, pp. 253-279

Juliana, (2017), Peran Syariahpreneur Dalam Mewujudkan Kesejahteraan Masyarakat: Studi Pada Bisnis Properti di Wilayah Bandung Raya, Disertasi, SPS UIN Syarif Hidayatullah, Jakarta

J., Effendi, L. M. Baga, I. S Beik dan T. Nursyamsiah, Aplikasi Model Bisnis Microfinance Syariah Terhadap Sektor UMKM di Indonesia, Iqtishodia, volume 10 nomor 2 2017. Pp 120-152

J. Juliana, M. Adib Sulthan, \& Muhammad Fathir. Islamic Business Ethics: Case Study of Puspa Sharia Micro Business Actors in Bank Indonesia West Java Region in Bandung 2017. Journal Review of Islamic Economics amd Finance Volume 1, Numbe 2, June 2019. Hal 31-37 
J. Juliana, Feby Syahril Qudsi, Disman Disman \& Ropi Marlina. (2018). Sharia Compliance: Case Study on Murabahah Product BMT ItQan. $2^{\text {nd }}$ ICIEBP (p. $914-$ 923). Surabaya: KnE Social Sciences.

Kaunang, W. R. (2013). Daya Saing Ekspor Komoditi Minyak Kelapa Sulawesi Utara. Jurnal Emba, 1304-1316.

Kementrian KUMKM, Permen, hlm 3

Kuncoro, M. (2011). Metode Kuantitatif. Yogyakarta: UPP Sekolah Tinggi Ilmu Manajemen YKPN

Mahmudah, Nur Atiqah. (2012). Pengawasan Terhadap Bisnis Syariah di Indonesia. Jurnal Ekonomi dan Hukum Islam, Vol. 2, No. 2

Matlay, H., "Entrepreneurship Education in UK Business Schools: Conceptual, Contextual and Policy Consideration", Journal of Small Business and Enterprise Development, Vol. 12 No. 4, (2005), pp. 627-643.

M.Tohar. (1999). Membuka Usaha Kecil, Yogyakarta, Kanisius.

M. Zaidi A. (2003). Lembaga Perekonomian Ummat di Dunia Islam, Bandung : Angkasa.

Morduch, J. (1999): The microfinance promise, in: Journal of Economic Literature, Vol. 37, No. 4, pp. 1569-1614

NI Riwajanti, Islamic Microfinance: Challenges and Development, Jurnal Riset dan Aplikasi:

Revrisond Baswir. (2000). Koperasi Indonesia. Yogyakarta : BPFE, 2000 hlm 1

Sudaryanto, Ragimun, \& Wijayanti, R. R. (2013). Strategi Pemberdayaan UMKM Menghadapi Pasar Bebas Asean. Jurnal Kementrian Keuangan, 2.

Sugiarto dkk. 2001. Teknik Sampling. Jakarta: PT. Gramedia Pustaka Utama.

Sugiono. (2001). Statistika untuk Penelitian, Bandung: Alfabeta.

Suhartini. (2013). Faktor-faktor yang Mempengaruhi Analisis Daya Saing Sentra Industri Batik Berbasis Diamond Porter Modelling. Jurnal.

Schumpeter, J.A., The Theory of Economic Development, (Cambridge, MA: Harvard University Press, 1934).

Yunus, M. (2004): Grameen Bank at a glance http://www.grameeninfo.org/bank/GBGlance.htm (02.02.2004) 